\title{
SILIKON TERLARUT UNTUK PERTUMBUHAN DIATOM
}

\author{
Oleh \\ Hanny Meirinawati ${ }^{1}$
}

\begin{abstract}
DISSOLVED SILICON FOR DIATOM GROWTH. Silicon is the second most abundant element in the earth's crust. Silicon is an essential nutrient for diatom growth (Bacillariophyceae). Diatom require dissolved silicon to build silicate cell walls (frustule). Factors regulating diatom growth rate are cell size, concentration, heat, temperature, and concentration of Fe and Zn. The main source of dissolved silicon in the ocean is chemical weathering of rocks. The availability of dissolved silicon plays an important role in controlling the biogeochemical that regulates primary production, atmospheric $\mathrm{CO}_{2}$, climate and ocean circulation. Changes in Si:N and Si:P ratios can affect the phytoplankton composition. Beside that, the function of silicon can reduce carbon dioxide levels from the atmosphere. This paper aims to provide information on the process of the occurrence of dissolved silicon in the sea and the function of dissolved silicon especially for diatom growth.
\end{abstract}

\section{PENDAHULUAN}

Silikon adalah unsur yang melimpah kedua setelah oksigen di kerak bumi dimana sekitar 28,8\% berbentuk silikat mineral. Sumber utama silikon terlarut di laut adalah pelapukan kimia dari batuan terestrial yang akan melarutkan silikon dan dibawa oleh limpasan sungai masuk ke laut. Silika bertahan di dasar laut dan terkubur dalam sedimen. Umumnya di daerah temperate dan khatulistiwa, massa sedimen mengandung lebih dari sepertiga silika biogenik (Libes, 2009).

Silikon adalah sumber energi utama untuk rantai makanan di estuari dan pesisir. Silikon merupakan nutrien penting untuk pertumbuhan diatom (Bacillariophyceae). Silikon merupakan nutrien pembatas utama untuk pertumbuhan diatom dan faktor untuk mengontrol produktivitas primer. Diatom mengambil DSi (Dissolved Silicon) dan menggunakannya untuk membangun dinding sel silikat atau frustula (Tréguer et al., 1995). Diatom mentransfer energi ke tingkat trofik yang lebih tinggi sehingga diatom sangat penting terutama untuk bidang perikanan (Struyf et al., 2009).

\section{Siklus Biogeokimia Silikon}

Proses siklus biogeokimia silikon (Si) diawali dengan terjadinya pelapukan batuan beku yang menyebabkan pelepasan silikon dalam bentuk tanah liat, kemudian silikon akan terlarut melalui sungai ke laut dan terjadi interaksi sebagai silikon terlarut di laut. Silikon terlarut digunakan oleh diatom kemudian diatom mati dan melepaskan

\footnotetext{
1) Pusat Penelitian Oseanografi-LIPI
} 
kembali silikon. Partikulat silikon dan organisme mati kemudian tenggelam ke dasar laut dan akhirnya berubah menjadi batuan beku (Yilmaz, 2000). Ekosistem terestrial berperan dalam penggunaan, penyimpanan dan daur ulang pada siklus biogeokimia silikon (Ragueneau et al., 2006).

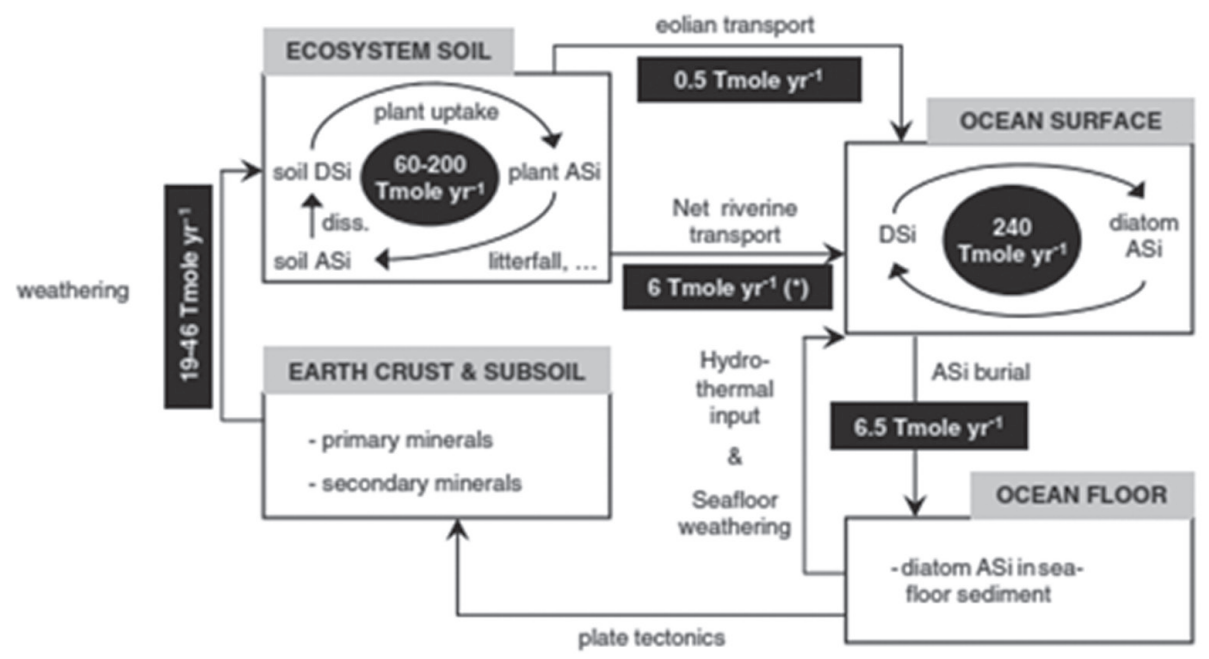

Gambar 1. Siklus Global Silikon (Struyf et al., 2009)

Proses pelapukan silikat menggunakan karbon dioksida $\left(\mathrm{CO}_{2}\right)$ akan menghasilkan asam ortosilikat terlarut dan lepas dari struktur mineral silikat. Reaksi proses pelapukan silikat sebagai berikut (Struyf et al., 2009):

$\mathrm{CaAl}_{2} \mathrm{Si}_{2} \mathrm{O}_{8}+2 \mathrm{CO}_{2}+8 \mathrm{H}_{2} \mathrm{O} \rightarrow \mathrm{Ca}^{2+}+$ $2 \mathrm{Al}(\mathrm{OH})_{3}+2 \mathrm{H}_{4} \mathrm{SiO}_{4}+2 \mathrm{HCO}_{3}^{-}$

$\mathrm{Ca}^{2+}+2 \mathrm{HCO}_{3}^{-} \rightarrow \mathrm{CaCO}_{3}+\mathrm{H}_{2} \mathrm{CO}_{3}$

Dari reaksi diatas dapat dikatakan bahwa pelapukan silikat merupakan salah satu cara penyerapan $\mathrm{CO}_{2}$ dari atmosfer. Konsumsi $\mathrm{CO}_{2}$ diperkirakan $0,26 \mathrm{Gt}$ $\mathrm{C} /$ tahun digunakan untuk pelapukan silikat (Hartmann et al., 2009). Sekitar $40 \%$ dari penyerapan karbon (1,5-2,8 $\mathrm{G}$ ton $\mathrm{C} /$ tahun) berkontribusi terhadap pertumbuhan dan sedimentasi diatom (Tréguer et al., 1995).

\section{DIATOM}

Diatom adalah organisme uniseluler yang dinding selnya mengandung silika dan merupakan komponen utama komunitas fitoplankton. Diatom merupakan anggota fitoplankton yang dominan di laut, terutama laut terbuka dengan ukuran berkisar $0,01-1,00$ $\mathrm{mm}$. Diatom adalah nama lain dari kelas Bacillariophyceae. Diatom secara istilah berarti dua bagian yang tidak dapat dibagi lagi yang mencerminkan struktur sel diatom. Dinding sel pada diatom terdiri dari dua katup (valve). Tipe dinding sel diatom merupakan karakter utama dalam pengklasifikasian diatom. Berdasarkan tipe dinding selnya, diatom dibagi menjadi dua bangsa yaitu Centrales dan Pennales (Hoek et al., 1995). 


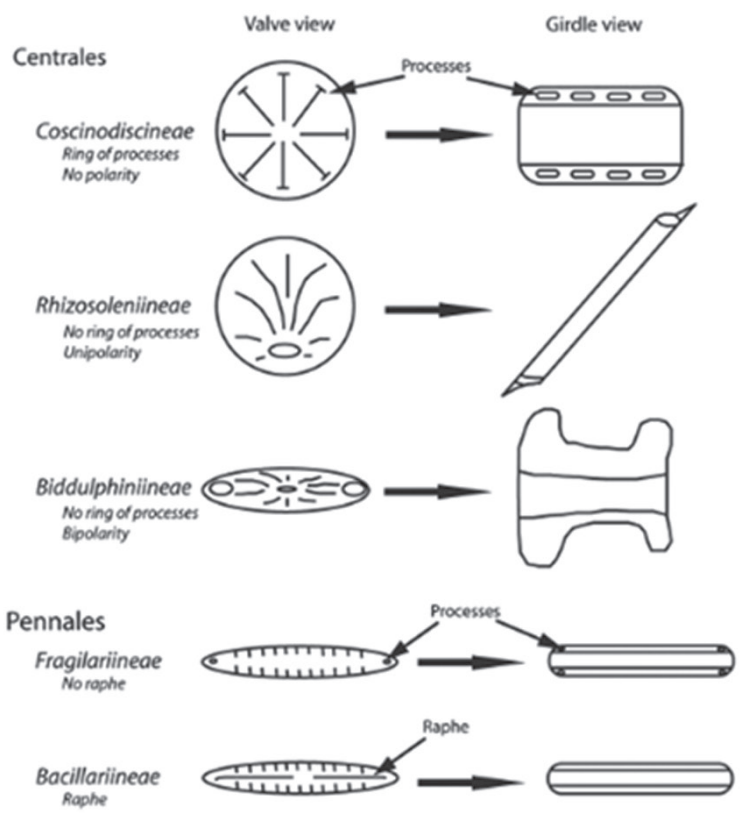

Gambar 2. Centrales dan Pennales (Crosta \& Koc, 2007)

Jumlah yang dikenali dari spesies diatom sekitar 10.000-12.000 jenis (Norton et al., 1996). Diperkirakan jumlah diatom sebesar $40 \%$ dari total produksi primer di laut (Nelson et al., 1995). Dinding sel diatom (Gambar 3), membentuk struktur silika rumit yang disebut frustula. Frustula mengandung
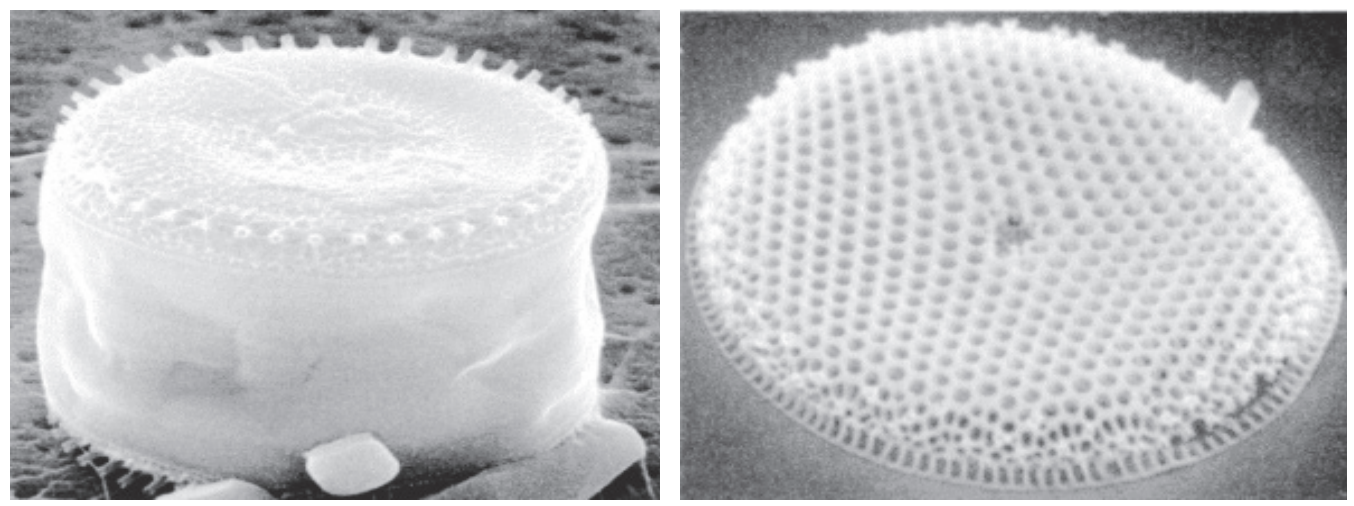

Gambar 3. Scanning electron micrographs sel Thalassiosira weisflogii dan katup spesies Thalassiosira (Jézéquel et al., 2000). 
Fungsi dari frustula diantaranya sebagai perlindungan terhadap predator, penyangga $\mathrm{pH}$ sehingga bentuk bikarbonat tidak berubah menjadi $\mathrm{CO}_{2}$, meningkatkan difusi nutrien sehingga terjadi penyerapan yang cepat ke dalam sel dan kontrol daya apung. Diatom memiliki kemampuan untuk menyimpan nutrien nitrat dan fosfat dalam vakuola dalam jumlah besar sehingga dapat bertahan hidup pada ketersediaan nutrien yang rendah (Libes, 2009).

Diatom merupakan kontributor terbesar dunia untuk biosilifikasi (pembentukan silika secara biologis). Keseluruhan proses silisifikasi melibatkan pengangkutan silikon melintasi plasmalemma dan kemudian melalui sitoplasma ke lokasi polimerisasi dalam vesikula pengendapan silika. Sel harus cukup mengangkut silikon untuk membuat dinding untuk mencegah autopolimerisasi yang terjadi di sitoplasma (Jézéquel et al., 2000).

Diatom sangat bergantung pada silika untuk membangun dinding sel biomineralisasi. Diatom laut mengendapkan $240 \times 10^{12} \mathrm{~mol}$ Si per tahun. Ketersediaan asam silikat terlarut (DSi) merupakan faktor pembatas untuk mengendalikan pertumbuhan diatom dan membentuk komposisi spesies. Zona pelagis dibatasi DSi di bawah 1 $\mu \mathrm{M}$, sedangkan zona bentik biasanya menunjukkan gradien kuat dan curam dengan DSi yang memiliki konsentrasi tinggi (sekitar $150 \mu \mathrm{M}$ ) dalam sedimen karena pelarutan mineral deposit (Bondoc et al., 2016). Contoh struktur kerangka mengandung silika dari diatom dan radiolaria dapat dilihat pada Gambar 4 dan 5.

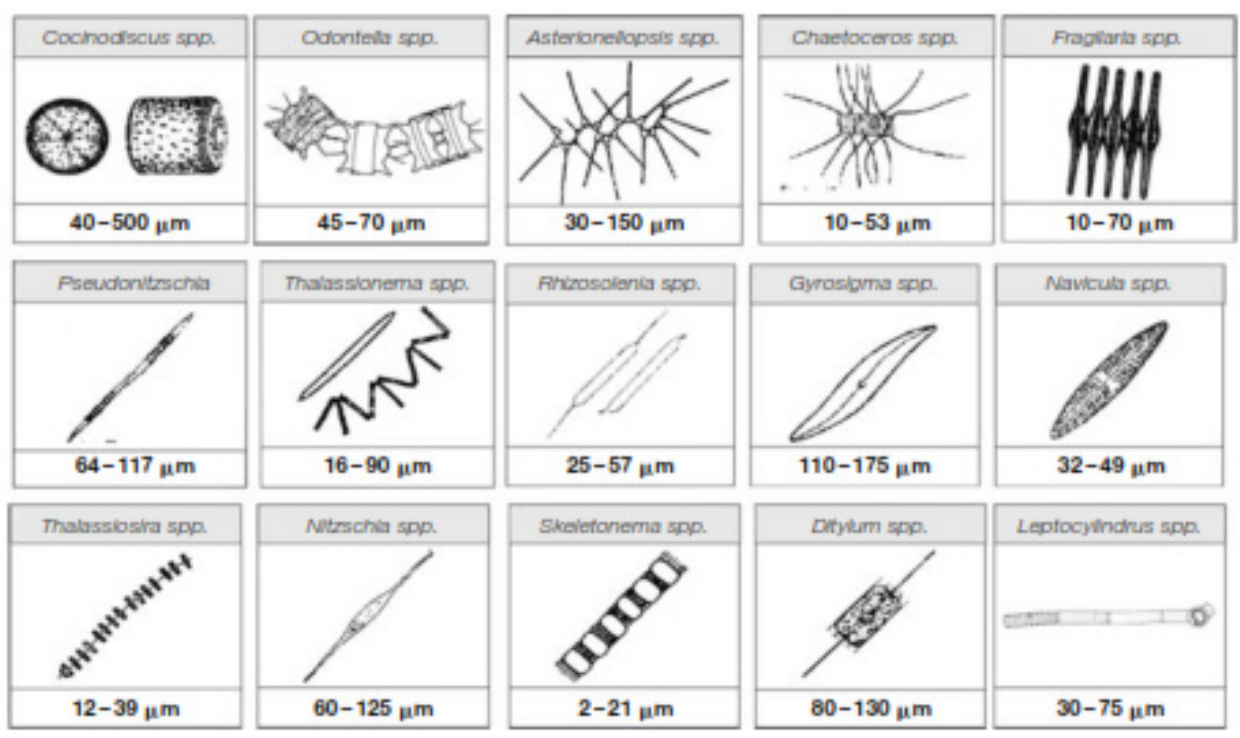

Gambar 4. Spesies diatom laut (Libes, 2009). 


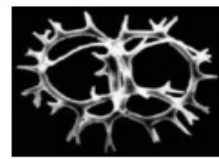

(a)

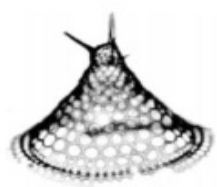

(f)

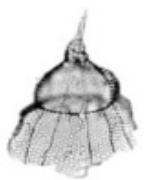

(k)

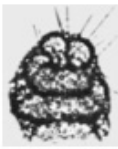

(b)

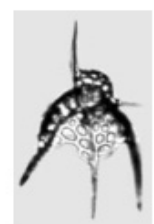

(g)

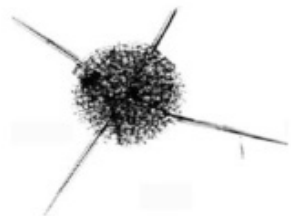

(I)

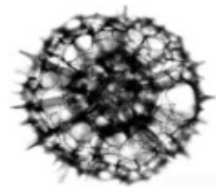

(c)

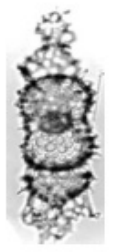

(h)

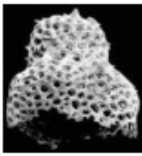

(d)

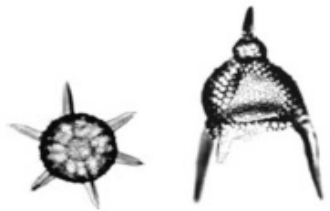

(i)

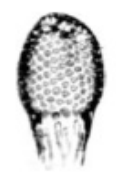

(e)

Gambar 5. Spesies radiolaria: (a) Acanthodesmia viniculata, (b) Botryocyrtis scutum, (c) Actinomma antarcticum, (d) Antarctissa denticulata, (e) Carpocanium spp. (f) Corocalyptra cervus, (g) Dictyophimus gracilipes, (h) Didymocyrtis tetrathalamus, (i) Hexacontium armatum/hostile group, (j) Pterocanium trilobum, (k) Pterocorys herwigii, (1) Spongosphaera streptacantha, (m) Spongotrochus glacialis, dan (n) Triceraspyris antarctica (Libes, 2009).

\section{PRODUKSI SILIKA BIOGENIK}

Mineral silikat yang terdiri dari silikon dan oksigen biasa disebut kuarsa. Kuarsa adalah kerangka silikat dengan rumus empiris $\mathrm{SiO}_{2}$ (silika). Silika juga terjadi dalam bentuk terhidrasi $\left(\mathrm{SiO}_{2} \cdot \mathrm{nH}_{2} \mathrm{O}\right)$, umumnya disebut silika amorf. Bagian keras mengandung silika yang diendapkan oleh plankton laut adalah jenis silika amorf yang disebut sebagai silika biogenik (BSi). BSi diproduksi oleh diatom, silicoflagellata dan juga radiolaria yang merupakan protozoa. Remineralisasi dari pelarutan BSi disebut sebagai silika terlarut (DSi)
(Libes, 2009).

Senyawa silikon terlarut yang dominan di air laut adalah asam ortosilikat $\left[\mathrm{H}_{4} \mathrm{SiO}_{4}(\mathrm{Aq})\right.$ atau $\left.\mathrm{Si}(\mathrm{OH})_{4}(\mathrm{Aq})\right]$. Sekitar lima persen disosiasi silikon terlarut berada dalam bentuk $\mathrm{H}_{3} \mathrm{SiO}_{4}^{-}(\mathrm{Aq})$. Silikon organik kompleks terlarut tidak terjadi secara alami. Struktur asam silikat menunjukkan geometri tetrahedral dengan atom silikon di pusat dan kelompok hidroksil menempati masing-masing dari empat sudut. Struktur ini mirip dengan mineral silikat tetrahedral. Pelapukan mineral silikat merupakan sumber utama silikat terlarut (DSi) (Libes, 2009). 


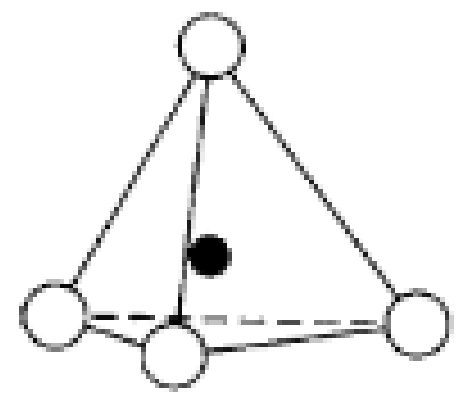

Gambar 6. Struktur mineral silikat tetrahedral (Libes, 2009).

\section{Penyerapan Silikon Terlarut}

Pengendapan BSi adalah mekanisme yang menyebabkan konsentrasi silikon terlarut berkurang. Sebagian besar BSi diendapkan oleh plankton di permukaan dan menjaga konsentrasi DSi di permukaan menjadi rendah $(<5$ $\mu \mathrm{M})$ (Libes, 2009). Distribusi vertikal konsentrasi silikon terlarut cenderung meningkat seiring dengan kedalaman dan konsentrasinya berkisar antara 1 sampai $100 \mu \mathrm{M}$ (Yilmaz, 2000).

Konsentrasi DSi yang tertinggi terjadi di daerah upwelling karena nutrien dari lapisan dalam terangkat ke lapisan permukaan akibat dorongan angin dan transportasi Ekman. Oleh karena itu, laju pertumbuhan diatom di lapisan permukaan dipengaruhi suplai DSi melalui upwelling. Sisa-sisa dari organisme mati yang mengandung silika tenggelam menuju lantai laut (Libes, 2009).

Ketersediaan silikon terlarut mengontrol pertumbuhan diatom yang bertanggungjawab sekitar setengah dari produksi primer bersih laut global. Ketersediaan silikon memainkan peran penting dalam mengendalikan biogeokimia yang mengatur produksi primer, $\mathrm{CO}_{2}$ dari atmosfer, iklim dan sirkulasi laut (Libes, 2009).

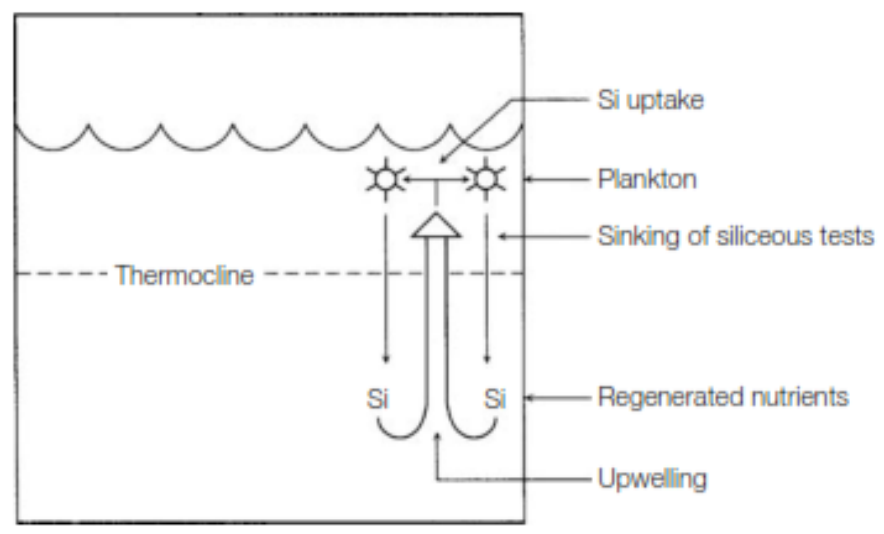

Gambar 7. Pemanfaatan silika di daerah upwelling (Libes, 2009). 


\section{FAKTOR YANG MEMENGARUHI SILISIFIKASI}

Jumlah silika dalam spesies diatom bervariasi hingga empat kali lipat (Brzezinski et al., 1990). Tingkat pertumbuhan diatom bergantung pada ukuran sel yaitu sel yang lebih besar tumbuh lebih lambat bahkan dalam spesies sama (Taylor, 1985). Sel lebih besar dari satu spesies secara alami memiliki lebih banyak silika daripada sel yang lebih kecil karena dari ukuran fisik yang lebih besar dari masing - masing komponen frustula. Oleh karena itu, baik ukuran sel maupun ketebalan frustula dapat berkontribusi pada variasi tingkat silisifikasi (Jézéquel et al., 2000).

Pembelahan sel dan pertumbuhannya berdampak langsung pada silisifikasi. Faktor seperti konsentrasi silikon eksternal dan kondisi pertumbuhan eksternal lainnya seperti cahaya, suhu, dan konsentrasi nutrien ( $\mathrm{N}$ dan $\mathrm{P}$ ) atau ion logam berat ( $\mathrm{Fe}$ dan $\mathrm{Zn}$ ) terlibat dalam pengaturan tingkat pertumbuhan. Oleh karena itu secara tidak langsung faktor tersebut terlibat dalam pengendalian silisifikasi (Jézéquel et al., 2000).

Di lingkungan alami mereka, komunitas fitoplankton mengalami perubahan lingkungan seperti meningkatnya suhu, keasaman dan konsentrasi nutrien. Komunitas fitoplankton akan merespons secara berbeda terhadap perubahan ini, namun untuk bertahan organisme ini perlu menyesuaikan diri dan akhirnya beradaptasi secara memadai. Salah satu adaptasi diatom terhadap perubahan lingkungan yaitu ketika konsentrasi silikon menurun tetapi konsentrasi nutrien lainnya berlebih. Hal yang terjadi yaitu siklus sel melambat sehingga pertumbuhan melambat. Di lingkungan silikon yang terbatas, jumlah dari silisifikasi per sel juga menurun sehingga dinding sel lebih tipis. Akibatnya pembelahan sel bisa terjadi bahkan pada saat jumlah Si rendah (Javaheri et al., 2015).

Endapan silika dalam diatom dipengaruhi oleh ketersediaan unsur hara dalam medium. Diatom hanya terbelah ketika katup sel induk disintesis sehingga siklus sel dan pertumbuhan diatom dikendalikan oleh tersedianya silikon. Oleh karena itu, ketika kekurangan silikon maka siklus sel akan berhenti (Javaheri et al., 2015).

\section{PENGARUH SILIKAT TERHADAP KOMPOSISI FITOPLANKTON}

Dominasi diatom dalam komunitas fitoplankton telah bergeser dari waktu ke waktu. Aktivitas manusia dari darat cenderung mengurangi konsentrasi silikon ke laut. Salah satunya diakibatkan dari penggunaan pupuk yang berlebihan. Nitrogen dan fosfor akan meningkatkan pertumbuhan diatom sehingga mengurangi konsentrasi silikon terlarut di perairan sungai yang mengalir ke laut (Libes, 2009).

Penelitian tahun 2014 mengenai komposisi komunitas fitoplankton di Laut Hitam bagian Tenggara menyatakan bahwa kelimpahan dinoflagellata 
meningkat dan menjadi kelompok yang dominan. Dari 89 spesies yang ditemukan, diantaranya $71 \%$ dinoflagellata, $23 \%$ diatom, dan $6 \%$ spesies lain. Oleh karena itu dapat di katakan bahwa di Laut Hitam bagian Tenggara telah terjadi pergeseran komunitas fitoplankton (Agirbas et al., 2014).

Dominasi diatom terjadi jika konsentrasi silikat melebihi ambang batas kira-kira $2 \mu \mathrm{M}$. Dominasi flagellata berubah menjadi dominasi diatom dalam beberapa hari setelah penambahan unsur hara sehingga menghasilkan konsentrasi silikat di atas ambang batas. Laju pertumbuhan diatom akan terlihat pada saat konsentrasi silikat tidak terbatas (Egge \& Aksnes, 1992).

Perubahan komposisi nutrien memengaruhi komposisi fitoplankton. Komunitas fitoplankton dapat dibagi menjadi dua kategori dasar yaitu didominasi oleh diatom dan didominasi oleh bentuk flagellata atau non diatom. Pertumbuhan diatom tergantung dari keberadaan silikat sedangkan pertumbuhan nondiatom tidak bergantung pada keberadaan silikat. Keberadaan komunitas flagellata sering dikaitkan dengan efek dari eutrofikasi (Egge \& Aksnes, 1992).

Nitrogen (N) dan silikon (Si) merupakan nutrien anorganik mendasar yang dibutuhkan untuk pertumbuhan diatom. Masukan antropogenik nitrogen dari pertanian dan sumber rumah tangga ke pesisir telah meningkat selama beberapa dekade terakhir. Perubahan dari $\mathrm{N}$ ke Si akan sangat berpengaruh terhadap kuantitas (jumlah sel dan biomassa) dan kualitas (komposisi biomassa) populasi diatom (Gilpin et al., 2004).

\section{EUTROFIKASI DI PESISIR}

Silikon memainkan peran penting dalam masalah eutrofikasi di ekosistem estuari dan pesisir. Peningkatan masukan nitrogen dan fosfor ke perairan dapat menyebabkan tejadinya eutrofikasi yang berdampak pada menurunnya jumlah silikat. Eutrofikasi menyebabkan peningkatan rasio nutrien $\mathrm{N}: \mathrm{Si}$ dan $\mathrm{P}: \mathrm{Si}$ (Egge \& Aksnes, 1992).

Kekurangan $\mathrm{Si}$ bisa mengubah ekosistem dari diatom ke nondiatom, yang biasa didominasi flagellata (Conley et al., 1993). Penurunan rasio Si:N dan Si:P dapat menyebabkan pengurangan diatom dan peningkatan jumlah nondiatom dari komunitas fitoplankton. Ledakan nondiatom dapat mengandung spesies yang berbahaya seperti Phaeocystis sp., Gonyulax sp., dan Chrysochromulina sp. (Smayda, 1997). Selain itu, ledakan nondiatom bisa menyebabkan kondisi anoksik dan peningkatan kekeruhan air (Struyf et al., 2009).

\section{PENUTUP}

Silikon merupakan salah satu unsur penting untuk pertumbuhan diatom. Saat ini telah terjadi penurunan jumlah silikon diakibatkan peningkatan jumlah nitrogen dan fosfor dari aktivitas manusia. Penurunan konsentrasi silikon akan berdampak pada eutrofikasi. Selain itu, terjadi perubahan rasio $\mathrm{N}: \mathrm{Si}$ akan 
menurunkan kuantitas dan kualitas dari populasi diatom dan akan mengakibatkan terjadinya pergeseran komunitas diatom menjadi komunitas flagellata.

\section{DAFTAR PUSTAKA}

Agirbas, E., A. M. Feyzioglu, U. Kopuz, and C. A. Llewellyn. 2014. Phytoplankton community composition in the southeastern Black Sea determined with pigments measured by HPLC-CHEMTAX analyses and microscopy cell counts. $J$. Mar. Biol. Assoc. U. K. 95 :118.

Bondoc, K. G. V., J. Heuschele, J. Gillard, W. Vyverman and G. Pohnert. 2016. Selective silicate-directed motility in diatoms. Nature Communications 7:10540.

Brzezinski, M. A., R. J. Olson and S. W. Chisholm. 1990. Silicon availability and cell-cycle progression in marine diatoms. Mar. Ecol. Prog. Ser. 67:83-96.

Conley, D. J., C. L. Schelske and E. F. Stoermer. 1993. Modification of the biogeochemical cycle of silica with eutrophication. Mar. Ecol. Prog. Ser. 101:179-192.

Crosta, X and N. Koc. 2007. Diatoms: From Micropaleontology to Isotope Geochemistry. Developments in Marine Geology Volume 1 Elsevier B.V. pp 327-358
Egge, J. K. and D. L. Aksnes. 1992. Silicate as regulating nutrient in phytoplankton competition. Mar. Ecol. Prog. Ser. 83: 281289.

Gilpin, L. C. , K. Davidson and E. Roberts. 2004. The influence of changes in nitrogen: silicon ratios on diatom growth dynamics. Journal of Sea Research 5:2135.

Hartmann, J., N. Jansen, H. H. Dürr, A. Harashima, K. Okubo and S. Kempe. 2009. Predicting riverine dissolved silica fluxes to coastal zones from a hyperactive region and analysis of first-order controls. Int. J. Earth Sci. 99:207-230.

Hoek, C. V. D., D. G. Mann and H. M. Jahns. 1995. Algae: an introduction to phycology. Cambridge University Press., Cambridge: $627 \mathrm{pp}$.

Javaheri, N., R. Dries, A. Burson, L. J. Stal, P. M. A. Sloot and J. A. Kaandorp. 2015. Temperature affects the silicate morphology in a diatom. Scientific Reports $5: 1-9$.

Jézéquel, M. V., M. Hildebrand, and M. A. Brzezinski. 2000. Review Silicon Metabolism in Diatoms: Implications for Growth. $J$. Phycol. 36: 821-840.

Libes, S. 2009. Introduction to Marine Biogeochemistry. Second Edition. Academic Press, 925pp. 
Nelson, D. M., P. Tréguer, M. A. Brzezinski, A. Leynaert and B. Queguiner. 1995. Production and dissolution of biogenic silica in the ocean: revised global estimates, comparison with regional data and relationship to biogenic sedimentation. Global Biogeochem. Cycl. 9:359-372.

Norton, T. A., M. Melkonian and R. A. Andersen. 1996. Algal biodiversity. Phycologia 35:353-365.

Ragueneau, O., S. Schultes, K. Bidle, P. Claquin and B. Moriceau. 2006. Si and C interactions in the world ocean: importance of ecological processes and implications for the role of diatoms in the biological pump. Glob. Biogeochem. Cycles 20: GB4S02.
Smayda, T. J. 1997. Bloom dynamics: physiology, behavior, trophic effects. Limnol. Oceanogr. 42:1132-1136.

Struyf, E., A. Smis, S. Van Damme, P. Meire and D. J. Conley. 2009. The Global Biogeochemical Silicon Cycle. Silicon 1: 207213.

Taylor, N. J. 1985. Silica incorporation in the diatom Coscinodiscus granii as affected by light intensity. Br. Phycol. J. 20: 365-374.

Tréguer, P., D. M. Nelson, A. J. van Bennekom, D. J. DeMaster, A. Leynaert and B. Quéguiner. 1995. The silica balance in the world ocean: a reestimate. Science 268: 375-379

Yilmaz, A. 2017. Topic 14: Nutrients. www.ioccg.org/training/ turkey/DrYilmaz_lecture2. pdf. Diakses pada tanggal 22 Desember 2017. 